Article

\title{
Ingested Microplastics in 18 Local Fish Species from the Northwestern Mediterranean Sea
}

\author{
Mel Constant ${ }^{1,2, *(\mathbb{D}}$, Mathieu Reynaud ${ }^{1,2} \mathbb{D}$, Lisa Weiss ${ }^{1,2} \mathbb{D}$, Wolfgang Ludwig ${ }^{1,2}$ and Philippe Kerhervé ${ }^{1,2}$ \\ 1 Centre de Formation et de Recherche sur les Environnements Méditerranéens, UMR 5110, \\ Université de Perpignan Via Domitia, 52 Avenue Paul Alduy, F-66860 Perpignan, France; \\ mathieu.reynaud62@gmail.com (M.R.); lisa.weiss@univ-perp.fr (L.W.); ludwig@univ-perp.fr (W.L.); \\ kerherve@univ-perp.fr (P.K.) \\ 2 Centre de Formation et de Recherche sur les Environnements Méditerranéens, UMR 5110, \\ Centre National de la Recherche Scientifique (CNRS), 52 Avenue Paul Alduy, F-66860 Perpignan, France \\ * Correspondence: mel.constant@lilo.org
}

Citation: Constant, M.; Reynaud, M.; Weiss, L.; Ludwig, W.; Kerhervé, P. Ingested Microplastics in 18 Local Fish Species from the Northwestern Mediterranean Sea. Microplastics 2022, 1, 186-197. https://doi.org/ 10.3390/microplastics1010012

Academic Editor:

Nicolas Kalogerakis

Received: 25 January 2022

Accepted: 18 February 2022

Published: 1 March 2022

Publisher's Note: MDPI stays neutral with regard to jurisdictional claims in published maps and institutional affiliations.

Copyright: (C) 2022 by the authors. Licensee MDPI, Basel, Switzerland. This article is an open access article distributed under the terms and conditions of the Creative Commons Attribution (CC BY) license (https:// creativecommons.org/licenses/by/ $4.0 /)$.

\begin{abstract}
Plastic waste and its fragments (microplastics, $<5 \mathrm{~mm}$ ) are a global, persistent, and ubiquitous threat for land and marine ecosystems. We have investigated the occurrence and composition of microplastics within 18 coastal fish species of the northwestern Mediterranean Sea. Digestive tracts were digested using hydrogen peroxide, and residues were observed under a stereo-microscope. Suspected microplastics were analyzed with a Fourier Transform InfraRed (FTIR) spectrometer to confirm its plastic nature and to identify the polymer type. A rigorous blank control and FTIR correction was applied, leading to the removal of $78 \%$ of the initially sorted and suspected particles. Corrected concentrations range from 0.00 to 5.15 items per fish, a result within the same range than this has been reported for other coastal species previously investigated in this area. Fibers, made of polyester (PES), polyamide (PA), acrylic (A) and polypropylene (PP), largely dominate the microplastic shapes (91\%). A single driving force could not be identified, but several species traits (morphology, feeding, and habitat) may influence the number of ingested microplastics.
\end{abstract}

Keywords: marine litter; Gulf of Lion; marine vertebrates; contamination; digestive tracts

\section{Introduction}

Among the wide diversity of materials constituting marine litter (e.g., glass, paper, wood, metal), plastic is the most numerous component found on beaches, sea surfaces and floors [1]. Concerns about marine litter pollution began five decades ago with the discovery of plastics in $74 \%$ of stomachs of dead chick Laysan albatrosses (Phoebastria immutabilis) along the isolated islands of Hawaii [2]. Few years later, plastic litter has been described inside a wide range of marine animals, including zooplankton, benthic invertebrates, fishes, birds, top predators and cetaceans [3-8]. Contact with marine litter through ingestion or entanglement may induce blockage of the digestive tract, immobility or struggle and lead to death by starvation, predation or injury $[9,10]$. Marine litter may also affect marine ecosystems by carrying pollutants and invasive species across the oceans $[11,12]$ and by interfering with chemical communication [13].

The plastic production reached 368 million tons in the world in 2019 [14]. The large diversity of properties of plastic, e.g., resistance, flexibility, durability and ease of processing, coupled with a relatively low production cost, makes it an essential product for many applications but also a persistent pollutant when discarded into the environment [15]. Its resistance to complete degradation depends on several factors including solar radiation, heat, oxygen supply and mechanical perturbation [16]. Indeed, fragmentation of plastics stranded on the continent and beaches or floating at the sea surface is faster than fragmentation of immersed plastics [16]. Degradation processes yield small plastic particles $(<5 \mathrm{~mm})$, 
commonly named microplastics (MPs), which are more numerous than larger pieces. MPs may also come from manufactured micro-size plastics (e.g., from cosmetics [17]).

Once in the oceans, MPs can be ingested through feeding or respiration by organisms of all size classes and be transported through the water column $[18,19]$. If egested with faeces, microplastics can significantly alter the sinking rates of faecal pellets and thus lower the efficiency of the biological pump [20]. In addition, several studies have demonstrated experimentally the transfer of MPs to higher trophic levels in the food web (e.g., mussel to crab [21] or copepods to jellyfish [22]). In addition, their large surface areas increase their capacity to adsorb pollutants or to carry invasive or pathogen species [11,12]. MPs are included among the descriptors of the Good Environmental Status defined by the European Marine Strategy Framework Directive [23], which requires Member States to monitor them within four marine compartments: coastlines, sea surfaces, marine sediments, and biota.

The Mediterranean Sea, although it only represents $0.7 \%$ of the world's ocean area, [24] hosts $28 \%$ of endemic species, $7.5 \%$ of the world's marine fauna and $18 \%$ of the world's marine flora. The area is highly exposed to marine litter pollution [25-29] because of its semi-enclosed basin coupled with a highly anthropized coastline. Mediterranean shores host high population densities, receive waters from densely populated river catchments and is one of the most popular tourist destination in the world [30]. At least 134 species have been identified as being impacted by marine litter in the Mediterranean Sea [27]. MPs have consequently been observed in various species in the Mediterranean Sea [28] but only three species were studied in the Gulf of Lion (Clupea harengus, Sardina pilchardus, and Engraulis encrasicolus) [31-35]. Thus, the aim of this study was to improve our knowledge on MP impacted fishes in the Gulf of Lion, one of the most productive Mediterranean areas. We examined the presence of MPs within 18 local and coastal fish species and assessed their concentrations and their qualitative properties such as their shapes and polymer composition. We further analyzed these data in the search for patterns between the level of MP contamination and traits of the life of the different species (i.e., food and habitat preferences).

\section{Materials and Methods}

\subsection{Study Area}

The Gulf of Lion is a river-dominated continental margin covering $11,000 \mathrm{~km}^{2}$ from Cap Croisette in the northeast to Cap Creus in the southwest (Figure 1). This northwestern Mediterranean region is characterized by dense coastal populations and large supplies of freshwater, sediments, nutrients and contaminants [36-38]. The Rhône River (discharging to the Gulf of Lion) currently represents the highest freshwater input into the Mediterranean Sea. Inputs of particulate matter to the gulf originate mainly from the Rhône River (on average $95 \%$ of the total inputs) but other small coastal rivers (Hérault, Orb, Aude, Agly, Têt and Tech) can also carry large amounts of freshwater, sediments and contaminants during intense flash floods [39]. The sea floor along the coast is dominated by a sandy shore habitat and the rocky habitats are only found in the southernmost part of the Gulf of Lion [40]. The strong Northern Current runs along the continental slope of the Gulf of Lion from northeast to southeast.

\subsection{Sample Collection}

Digestive tract were opportunistically obtained from another research team of the university of Perpignan (see acknowledgment), already gathered by species in plastic beakers. Fishes were collected by divers along the rocky coast or bought at local fish markets (already dead, no killing was performed during this study). All species have been fished or captured within the study area at the southern part of the Gulf (Figure 1). They were preserved in a cooling container and transported to the laboratory, where they were identified at the species level, weighed and measured. Then, the entire digestive tracts (from esophagus to the end of the intestine) were dissected, measured and gathered 
by species in individual clean plastic beakers. Beakers were frozen at $-20{ }^{\circ} \mathrm{C}$ until the extraction of MPs.

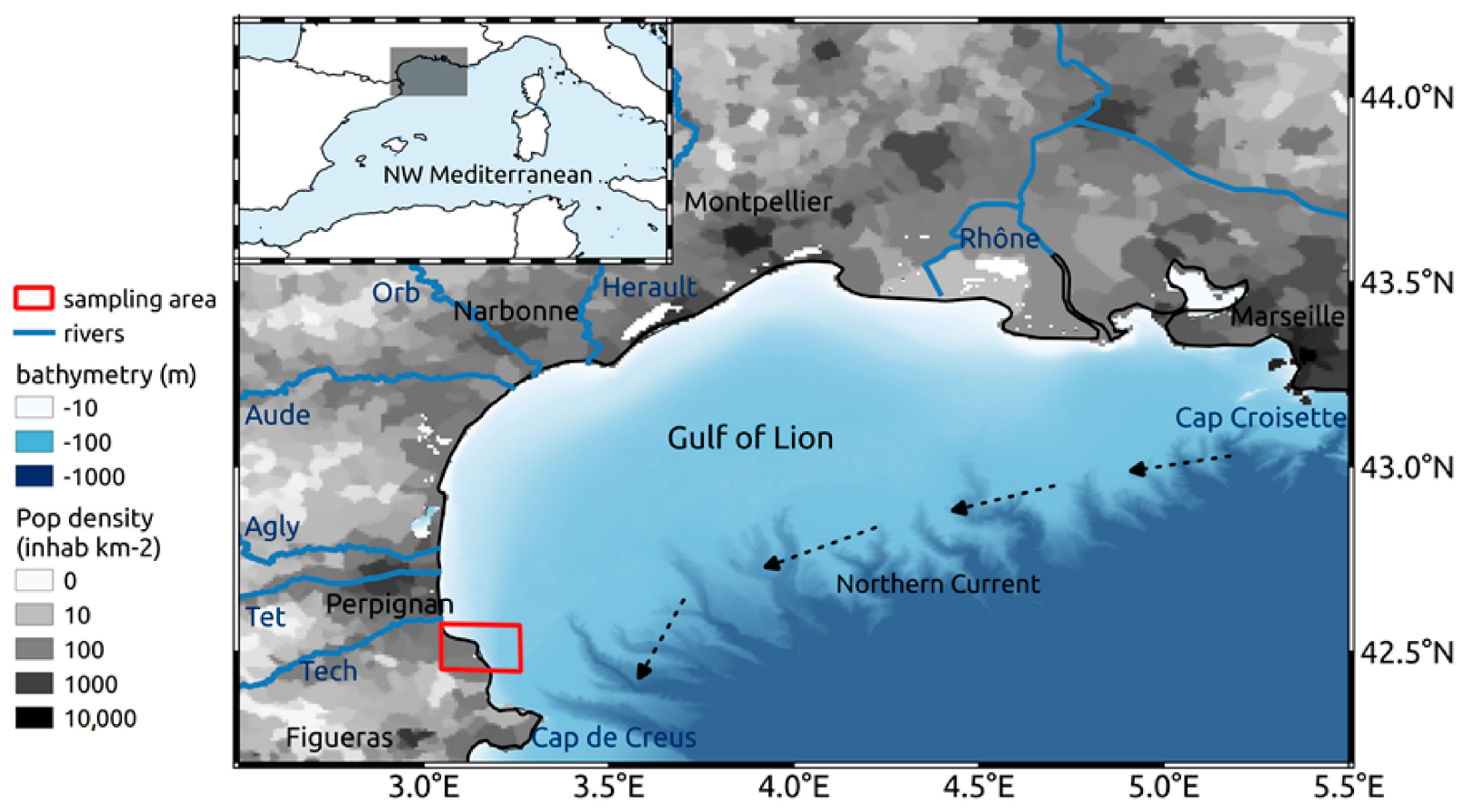

Figure 1. Location of the study area. General map of the northwestern Mediterranean Sea showing the location of the Gulf of Lion (shaded area). Gulf of Lion with location of the sampling area (red empty square).

\subsection{Extraction of MPs from Fish Tissues}

Contamination of samples was minimized by wearing laboratory cotton coats and by using glass or steel equipment and tools, rinsed with MilliQ ${ }^{\circledR}$ water (Merck KGaA, Darmstadt, Germany) and wrapped in aluminum foils. Several contamination control filters were simultaneously performed as blanks with MilliQ ${ }^{\circledR}$ water following the same procedures, as the digestive tracts, described hereafter. Digestive tracts were transferred to glass beakers and tissues were removed using hydrogen peroxide $\left(\mathrm{H}_{2} \mathrm{O}_{2} ;\right.$ modified from Avio et al. [41]). A total of $2 \mathrm{~mL}$ of $\mathrm{H}_{2} \mathrm{O}_{2}(40 \%)$ was added repeatedly until most of the tissues was digested. During the entire digestive process, beakers were heated at $50{ }^{\circ} \mathrm{C}$ on a heating plate. The resulting solutions were filtered on LLG $^{\circledR}$ filter papers (diameter: $47 \mathrm{~mm}$; porosity: $2 \mu \mathrm{m}$; Lab Logistics Group $\mathrm{GmbH}$, Meckenheim, Germany). Filters were dried at $50{ }^{\circ} \mathrm{C}$ overnight and then examined under a Wild Heerbrugg (Leica ${ }^{\circledR}$, Wetzlar, Germany) dissecting stereomicroscope $(6 \times, 12 \times, 25 \times$ and $50 \times$ magnification). The smallest size of MPs that can be accurately sorted with this microscope has been estimated to $100 \mu \mathrm{m}$, which means that a MP size range of $100 \mu \mathrm{m}$ to $5 \mathrm{~mm}$ could be investigated in our study. Particles were separated into only two shape categories: fibers (including filaments and fishing line) and fragments (items with a three-dimensional shape). No other shapes, such as solid spheres (beads), two-dimensional items (films) or pieces with a spongy or soft structure (foams) were found.

\subsection{Polymer Analysis with Fourier Transform InfraRed Spectroscopy}

A total of 31 fibers and 4 fragments found in fish guts were randomly selected and analyzed with a Spectra-Tech IR-PLAN ${ }^{\circledR}$ microscope (Spectra Tech Inc., Oak Ridge, TN, USA) coupled to a Bomem ABB $^{\circledR}$ FTLA FTIR spectrometer (ABB, Zurich, Switzerland) in order to verify their plastic nature and to determine their polymeric composition [42]. The identification of each polymer was performed by comparison with a self-collected spectrum database including polyethylene (PE), polypropylene (PP), polyamide (PA), polyvinyl chloride 
(PVC), polystyrene (PS), poly(ethylene-vinyl acetate) (PEVA), polyethylene terephthalate (PET), polyester (PES), polyurethane (PUT), acrylic (A) and some non-plastic materials such as cotton, wool, wood, paper, calcium carbonate, talcum powder and plant fibers. Only polymers reaching at least $70 \%$ of similarity with reference spectra were accepted, according to the suggestion of Thompson et al. [43].

\subsection{Data Analysis}

The highest number of suspected plastics found in blank laboratory control filters (10 fibers) was subtracted to the initial sorting to correct overestimation due to laboratory contaminants. In addition, FTIR analysis was used to remove the false-positive particles, i.e., non-plastic particles incorrectly sorted as "suspected plastic items" in our samples. An identified plastic ratio was calculated by dividing the number of particles with a real "plastic spectra" by the total number of suspected plastics. All MP results (contents and relative contents of shapes given in the following text, figures and tables) correspond to identified and spectrometrically verified MPs. Finally, mean concentrations of MPs (items fish $^{-1}$ ) were estimated by dividing the corrected numbers of MP items by the number of individuals for each species. As digestive tracts of fishes were pooled at the species level before extraction, concentrations per individual could not be estimated, and therefore, no standard deviation could be calculated, and no further statistical analysis could be performed.

\section{Results}

A total of 386 particles have been suspected to be MPs, consecutively sorted from the 107 fishes belonging to 18 species of the Mediterranean Sea (Table 1 and Figure 2A). After blank control and FTIR correction, it appears that only 85 items or $22 \%$ (identified plastic ratio) of the suspected MPs were really ingested MPs (Figures 2B and 3). The mean concentration of MPs was 0.80 items fish $^{-1}$ if we consider the total number of fishes, 1.00 items fish $^{-1}$ if the species without ingested MPs are removed and 0.31 items fish $^{-1}$ if we consider only the 5 taxa with 10 individuals and more (Table 1).

Table 1. Average numbers of microplastics (MPs) per fish (corrected values) and associated features of the different species. Size: Mean total length of fishes $(\mathrm{cm})$. Information on habitats and foods are given in [44-47].

\begin{tabular}{|c|c|c|c|c|c|c|c|}
\hline Species & $\begin{array}{c}\text { Number of } \\
\text { Fish }\end{array}$ & Size $(\mathrm{cm})$ & $\begin{array}{c}\text { Mean } \\
\text { Digestive } \\
\text { Tract Length } \\
(\mathrm{mm})\end{array}$ & Habitat & Type of Preys & Trophic Level & $\begin{array}{c}\text { Mean MPs } \\
\text { Per Fish }\end{array}$ \\
\hline Anthias anthias & 1 & 17 & 113 & reef-associated & small nektonic & $3.8 \pm 0.6$ & 1.05 \\
\hline Boops boops & 10 & 23 & 493 & demersal & small nektonic & $2.8 \pm 0.0$ & 0.52 \\
\hline Chromis chromis & 7 & 9 & 140 & reef-associated & small nektonic & $3.8 \pm 0.4$ & 0.65 \\
\hline Coris julis & 1 & 23 & 121 & reef-associated & small nektonic & $3.4 \pm 0.1$ & 1.05 \\
\hline Diplodus annularis & 10 & 17 & 203 & benthopelagic & small nektonic & $3.6 \pm 0.0$ & 0.10 \\
\hline Diplodus cervinus & 3 & 43 & 451 & benthopelagic & small nektonic & $3.0 \pm 0.4$ & 3.85 \\
\hline Diplodus puntazzo & 1 & 35 & 429 & benthopelagic & small nektonic & $3.2 \pm 0.0$ & 5.15 \\
\hline Diplodus sargus & 2 & 25 & 276 & demersal & small nektonic & $3.4 \pm 0.1$ & 0.00 \\
\hline Mugil cephalus & 3 & 75 & 1739 & benthopelagic & planktons & $2.5 \pm 0.2$ & 0.35 \\
\hline Pagellus erythrinus & 6 & 35 & 197 & benthopelagic & small nektonic & $3.5 \pm 0.1$ & 0.00 \\
\hline Sardina pilchardus & 13 & 19 & 145 & pelagic-neritic & $\begin{array}{c}\text { small } \\
\text { invertebrates }\end{array}$ & $3.1 \pm 0.1$ & 0.48 \\
\hline Scieana umbra & 8 & 38 & 351 & demersal & small nektonic & $3.8 \pm 0.5$ & 3.52 \\
\hline Spicara maena & 12 & 23 & 179 & pelagic-neritic & $\begin{array}{c}\text { small } \\
\text { invertebrates }\end{array}$ & $4.2 \pm 0.6$ & 0.46 \\
\hline Symphodus ocellatus & 8 & 9 & 66 & reef-associated & small nektonic & $3.5 \pm 0.0$ & 1.09 \\
\hline Symphodus roissali & 13 & 14 & 95 & reef-associated & small nektonic & $3.5 \pm 0.4$ & 0.00 \\
\hline Symphodus rostratus & 2 & 9 & 71 & reef-associated & small nektonic & $3.5 \pm 0.0$ & 1.40 \\
\hline Symphodus tinca & 6 & 28 & 228 & reef-associated & small nektonic & $3.3 \pm 0.3$ & 0.52 \\
\hline Uranoscopus scaber & 1 & 30 & 175 & benthic & $\begin{array}{l}\text { crustaceans } \\
\text { and fishes }\end{array}$ & $4.4 \pm 0.7$ & 0.00 \\
\hline
\end{tabular}


Shape $\square$ Fibers $\square$ Fragments

A Uncorrected numbers of MPs per fish

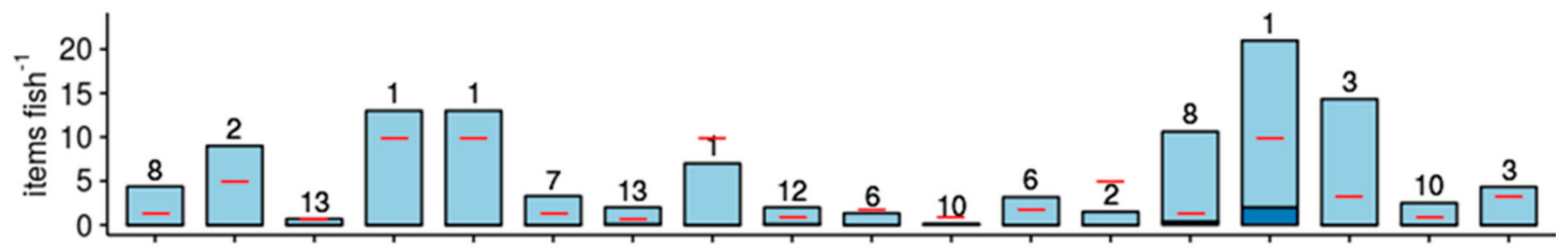

B Corrected numbers of MPs per fish (FTIR + blank control)
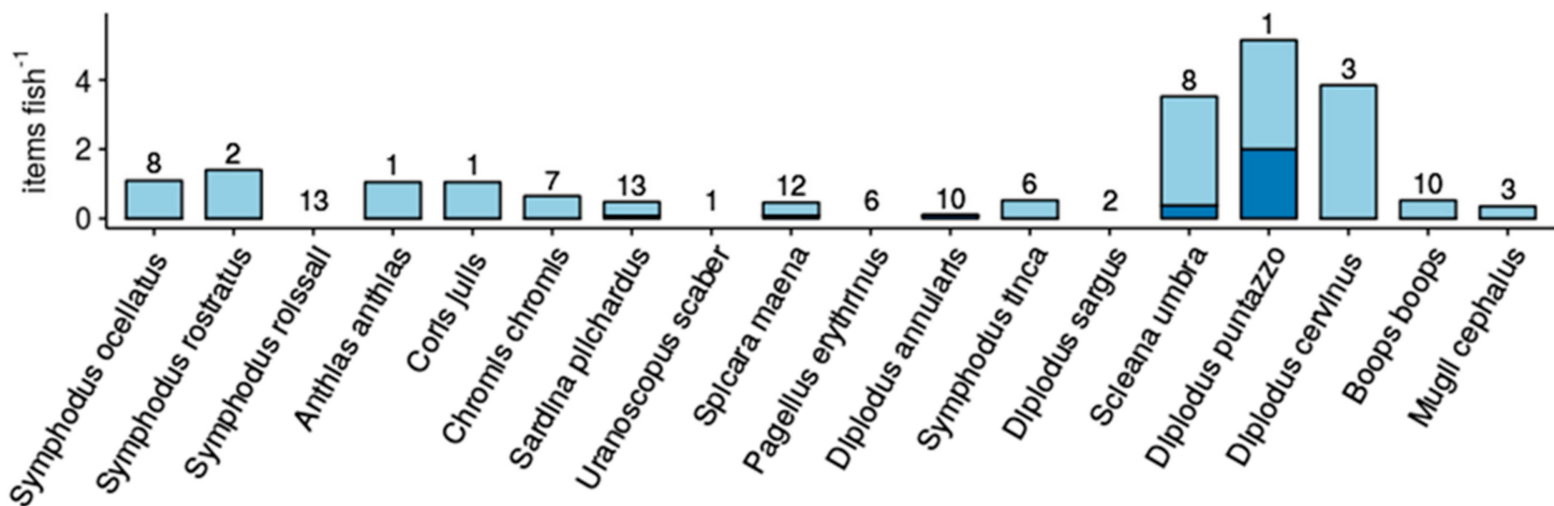

Taxon (shortest $\longrightarrow$ longest digestive tracts)

Figure 2. Uncorrected and corrected numbers of items per fish (items fish ${ }^{-1}$ ) for the 18 fish studied species. (A) Numbers of suspected MPs per fish, i.e., before Fourier Transform InfraRed (FTIR) and blank corrections. (B) Numbers of corrected MPs per fish. Red short line indicates the highest number of suspected MP found in all blank laboratory control filters (i.e., 10 items) divided by the number of fish examined per taxon. Colors indicate MP shapes, with light blue for fibers and dark blue for fragments. Numbers above bars indicate the number of fish examined per taxon. Taxa are ordered following the mean length of digestive tracts measured, with increasing length from left to right.
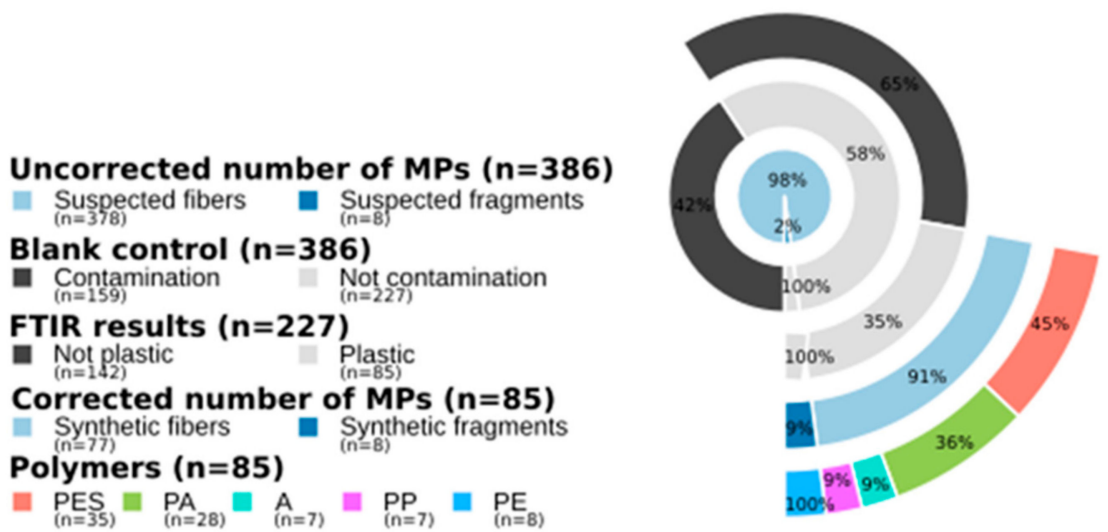

Figure 3. Relative shape distribution and synthetic organic polymer composition of suspected MPs (circles 1 and 2) and verified MPs (circles 3 and 4) found in the 18 fish species. Circle 1 (center): shape of the suspected MPs before FTIR and blank control correction. Circle 2: results of the FTIR analysis on randomly selected suspected MPs. Circle 3: shape of MPs after FTIR and blank control correction. Circle 4 (exterior): polymer composition of MPs. Except for the number of suspected MPs (circle 1), " $n$ " is an estimated number of MPs.

Mean concentrations of corrected MPs range from 0.00 to 5.15 items fish ${ }^{-1}$ within the 18 species (Table 1 and Figure 2B). Only 4 species (22 fishes) have no MP in their digestive tracts: $D$. sargus, P. erythrinus, S. roissali and U. scaber. 7 taxa (61 fishes) had MP 
concentrations lower than 1.5 MPs per fish and the remaining 3 species (12 fishes) had MP concentrations higher than 3 MPs per fish: D. cervinus, D. puntazzo, S. umbra.

Only fiber and fragment shapes were observed inside digestive tracks (Figure 3). FTIR results indicate that among the 31 randomly selected fibers only 11 were made of plastic $(35 \%)$. All tested fragments $(n=4)$ were made of PE. After FTIR and blank control corrections, MP fibers were still remain largely dominant (91\%) compared to fragments $(9 \%)$. About half of the 11 certified plastic fibers were made of PES $(n=5 ; 45 \%)$, slightly less were PA $(n=4 ; 36 \%)$, and only one fiber was made of A $(n=1 ; 9 \%)$ or PP $(n=1 ; 9 \%)$.

The three species with high MP mean concentrations ( $>3$ items fish $^{-1}$; Diplodus cervinus, Diplodus puntazzo, Scieana umbra) have different prey preferences than the others species and feed on small nektonic organisms or crustaceans and fishes (Figure 4B and Table 1). They also belong to the longest fishes (mean size) with the longest digestive tracts (mean length; Table 1 and Figure 2B). No undeniable differences in mean MP concentrations according to the fish position across the water column (Figure 4A) and prey preferences (Figure 4B) were noticed. No co-variation was observed between the trophic level and MP concentrations (Figure 4C).
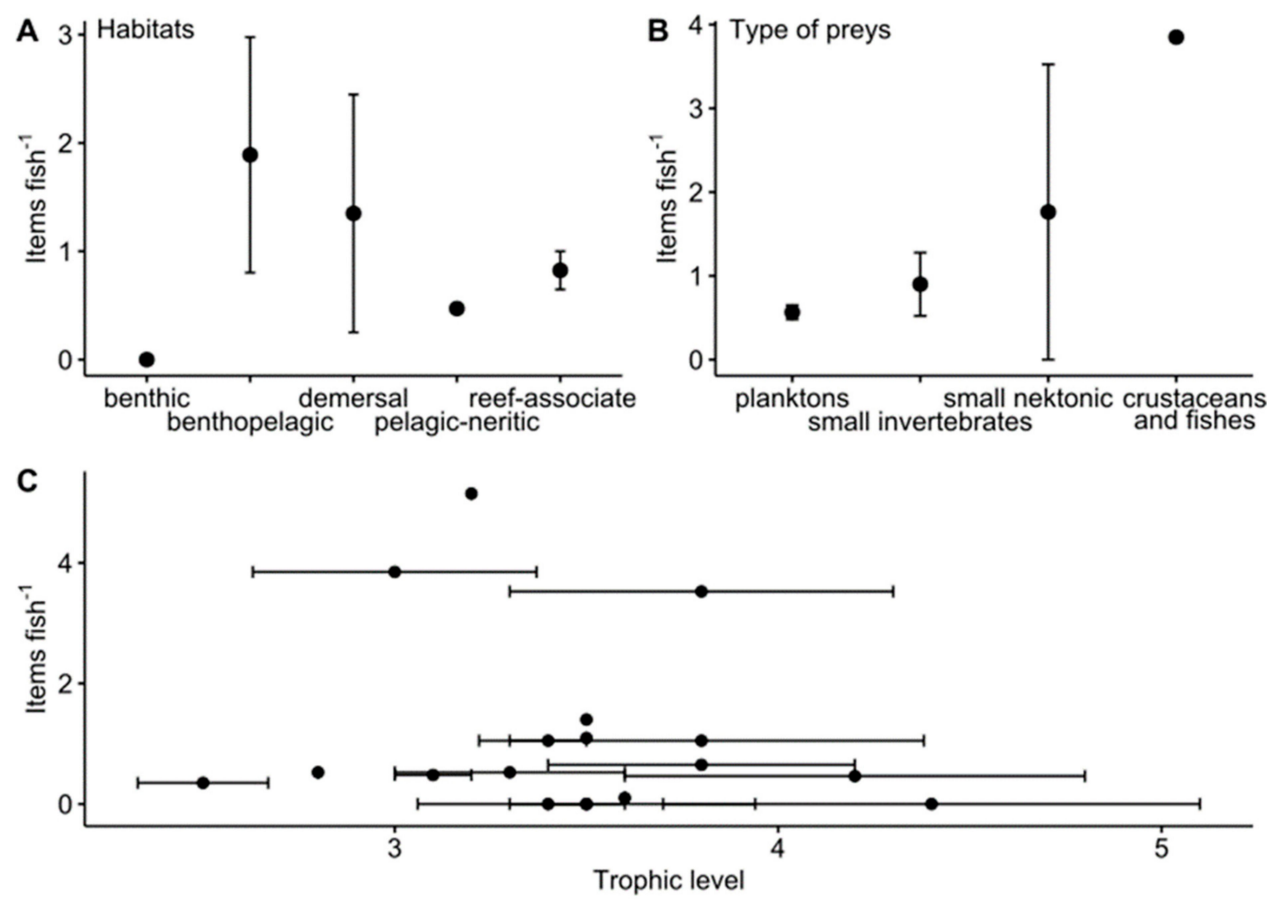

Figure 4. Mean MP concentrations per fish (items fish-1). (A) Concentrations within five groups of species pooled according to their habitats. (B) Concentrations for four groups of species pooled according to their prey preferences. (C) Concentrations according to the trophic level [47] of each species. The bars represent the standard deviation from the mean.

\section{Discussion}

\subsection{Mediterranean Fish Species Impacted by MPs}

Our study exhibited MP concentrations per fish that are close to the laboratory contamination. This result shows that a strict blank control procedure is required despite all the rigorous contamination control procedures. Additionally, the authentication procedure with an FTIR spectrometer is required, as $78 \%$ of the suspected MPs particles initially sorted were removed after both the blank control and the FTIR correction.

Blank corrected and FTIR verified MP concentrations of our 18 species of coastal fishes from the NW Mediterranean Sea varied within the same range $\left(<5.2\right.$ items fish $\left.^{-1}\right)$ than MP concentrations measured within previous studies (0.3-2.0 items fish ${ }^{-1}$; Table 2). In other locations of the Mediterranean Sea, Pellini et al. [48] and Anastasopoulou et al. [49] 
measured the highest concentration means in Adriatic fishes $\left(8.6\right.$ items fish ${ }^{-1}$ for S. solea and 9.5 items fish $^{-1}$ for $C$. auratus). These values are about twice as great than the highest mean MP concentration observed for D. puntazzo in our study (5.2 items fish ${ }^{-1}$ ). The Adriatic Sea focused several investigations on contamination of fishes with MPs and seems to exhibit the highest contents of MPs in Mediterranean fishes. This semi-enclosed basin with an almost closed oceanic circulation at the Strait of Otranto is bordered by $3.700 \mathrm{~km}$ of shores which attract many tourists and which collect one third of the continental freshwater that flows into the Mediterranean Sea. The Adriatic Sea is among the zones with the highest floating MP concentrations recorded in the Mediterranean Sea [50].

Unlike results from Mediterranean beaches [51], where high MP concentrations are coupled with high percentages of fibers, percentages of fibers inside fishes vary from low to high independently of total MP concentrations, i.e., some fishes with high concentrations had low percentages of fibers and others with low concentrations had high percentages of fibers. Among the 107 fishes of 18 species, fibers accounted, on average, for $91 \%$ of all MP items. In other literature studies, they represent in a few cases less than $50 \%[4,31,48]$, and are dominant in the majority of them [52-55], and sometimes even reached up to 97 and $100 \%[56,57]$. Fibers are definitely complex to accurately enumerate.

Synthetic fibers are among the most abundant MP shapes in oceans and beaches, and can originate from textile [58] but also from fishing nets [59]. Most of the ecotoxicological studies on MP impact on marine organisms used manufactured small microbeads and little is known about the consequence of other MP shapes as fibers on marine animals [60]. Fossi et al. [28] reported from the scientific literature and for the whole Mediterranean Sea 60 fish species contaminated by plastic debris whatever their sizes. This study added 14 new species to the 7 other coastal fish species previously investigated in the NW Mediterranean, that reach now the total number of 27 (Table 2).

Table 2. Synthesis of MP concentrations in coastal fishes of the northwestern Mediterranean Sea. The number of fish is the sum of fishes investigated in each study. The percentage of fish with MPs and MP concentrations (fish without MPs are included) are weighted average by the number of fish per study. ND: no data. * MP concentrations within fish with MPs (i.e., fish without MPs are excluded). Decimal values are rounded to the nearest integer.

\begin{tabular}{|c|c|c|c|c|}
\hline Species & Number of Fish & Fish with MPs & $\begin{array}{l}\text { Concentrations } \\
\text { (Items fish }^{-1} \text { ) }\end{array}$ & References \\
\hline Anthias anthias & 1 & & 1.1 & This study \\
\hline \multirow[t]{2}{*}{ Boops Boops } & 1750 & $50 \%$ & 0.8 & {$[56,61-64]$} \\
\hline & 10 & & 0.5 & This study \\
\hline Chromis chromis & 7 & & 0.7 & This study \\
\hline Coris julis & 1 & & 1.1 & This study \\
\hline Diplodus annularis & 10 & & 0.1 & This study \\
\hline Diplodus cervinus & 3 & & 3.85 & This study \\
\hline Diplodus puntazzo & 1 & & 5.2 & This study \\
\hline Diplodus sargus & 2 & & 0 & This study \\
\hline Mugil cephalus & 3 & & 0.35 & This study \\
\hline Mullus barbatus & 281 & $19 \%$ & 1.4 & {$[53,65,66]$} \\
\hline Mullus surmuletus & 417 & $27 \%$ & 0.4 & [57] \\
\hline Pagellus bogaraveo & 24 & $13 \%$ & ND & [67] \\
\hline \multirow[t]{2}{*}{ Pagellus erythrinus } & 15 & $6 \%$ & ND & [67] \\
\hline & 6 & $0 \%$ & 0 & This study \\
\hline Raya miraletus & 1 & $100 \%$ & 2.0 & [66] \\
\hline Spondyliosoma cantharus & 3 & $100 \%$ & $2.3 \pm 1.1^{*}$ & [54] \\
\hline \multirow[t]{2}{*}{ Sardina pilchardus } & 229 & $35 \%$ & 0.8 & {$[35,62,68]$} \\
\hline & 13 & & 0.5 & This study \\
\hline Scieana umbra & 8 & & 3.5 & This study \\
\hline Scorpaena sp. & 8 & $63 \%$ & $3.2 \pm 3.3 *$ & [54] \\
\hline Spicara maena & 12 & & 0.5 & This study \\
\hline Spondyliosoma cantharus & 3 & $100 \%$ & $2.3 \pm 1.1 *$ & [54] \\
\hline Symphodus ocellatus & 8 & & 1.1 & This study \\
\hline Symphodus roissali & 13 & & 0 & This study \\
\hline Symphodus rostratus & 2 & & 1.4 & This study \\
\hline Symphodus tinca & 6 & & 0.5 & This study \\
\hline & 16 & $19 \%$ & 0.3 & [66] \\
\hline \multirow[t]{2}{*}{ Uranoscopus scaber } & 6 & $83 \%$ & $2.4 \pm 1.7^{*}$ & {$[54]$} \\
\hline & 1 & & 0 & This study \\
\hline
\end{tabular}




\subsection{Impacted Fish Species: Relation with Their Food Supply and Their Habitat}

In this study, the high heterogeneity between the number of individuals per species as well as the lack of data per fish (fishes have been polled by species) does not allow to statistically test the differences between habitats and prey preferences. However, results (Table 1, Figure 3) suggest that fishes with large digestive tracks and fed by larger preys record the highest MP concentrations. Several previous studies $[54,69,70]$ investigated the MP concentrations in fishes from different trophic levels without detecting relationships between MP concentration inside fishes and trophic levels. Welden et al. [70] observed a transfer of MPs between a prey (A. tobianus) and its fish predator (P. platessa), but mean concentrations were similar between both species and the authors suggested that MPs are not significantly retained within the digestive tract of predators. Lusher et al. [6] came to the same conclusions after having found MPs throughout the whole digestive tract of fishes. Retention within the digestive tracts may be influenced by the length, the morphology and the straightness of these tracks. This may explain that the most impacted fishes in our study have the longest digestive tracts. Within the same trophic level, behavior of fishes in terms of feeding strategy or migration may also influence MP ingestion [71,72]. Romeo et al. [71] found no differences in MP concentration within bluefin tuna T. thynnus (opportunistic feeder) and albacore tuna T. alalunga (specialist feeder). Romeo et al. [72] observed within the same family, more MPs within species characterized by a migration behavior than without. At the species scale, MP ingestion may depend on fish size, weight, physical condition or stomach contents [48,52,54,55]. Alomar and Deudero [52] observed that fuller stomachs contained more MPs. Güven et al. [54] found no relation between fish length or fish mass and MP ingestion (all species were polled), whereas Pellini et al. [48] observed that in soles, small MPs $(<100 \mu \mathrm{m})$ were less abundant in larger fishes than in smaller fishes. Compa et al. [55] came to the same conclusions for S. pilchardus. As concluded by Fossi et al. [28], further studies are now needed at different scales and with sentinel species, to better understand the interactions between marine organisms and MP accumulation.

The habitats of our investigated fish species could also play a significant role in the contamination of MPs, but the relationships were less evident than in the case of the preferred preys. Indeed, the demersal species were slightly more contaminated than pelagic ones. At a larger spatial scale, fish habitats in the Mediterranean Sea and other oceans have been often proposed as an important forcing factor for MP accumulation [48,53,56,70]. With respect to potential sources of MP pollution in the sea, Alomar et al. [57] found no relation between MPs inside fishes and the sampling distance from the coast and the main sources of MPs as through rivers, harbors and coastal cities.

\section{Conclusions}

This study was carried out on the ingestion of MPs by 18 Mediterranean fish species, about which 14 were investigated for the first time. We confirm the widespread presence of MPs in Mediterranean fishes and are able to draw several major conclusions.

1. The quantification of MPs in fishes requires high methodological concerns and analytical confirmation. A total of $78 \%$ of the suspected plastic particles in our samples were actually not MPs;

2. We found that 4 species (D. sargus, P. erythrinus, S. roissali and $U$. scaber) were not contaminated by MPs and 3 species (D. cervinus, D. puntazzo, S. umbra) were found to have higher than average MP concentrations ( $>3$ MPs per fish). However, the number of investigated fishes per species was low and further investigations are needed to confirm this;

3. About $80 \%$ of our contaminated species did not exceed the concentration of 2 MPs per fish. A low MP ingestion rate and a rapid egestion through simple digestive tracks can explain this low accumulation;

4. Fiber is the main MP shape (91\%) found in fish digestive tracts. Their impact on marine life are nearly unknown; 
5. The length and the morphology of fish digestive tracts, the prey preferences and, with lesser evidence, the habitat may influence the concentration of MPs.

Author Contributions: Conceptualization, M.C., M.R. and P.K.; methodology, M.C. and P.K.; validation, M.C.; formal analysis, M.C., M.R, P.K., L.W. and W.L.; investigation, M.R.; writing-original draft preparation, M.C.; writing-review and editing, M.C., M.R, P.K., L.W. and W.L. All authors have read and agreed to the published version of the manuscript.

Funding: This research received no external funding.

Institutional Review Board Statement: Not applicable.

Informed Consent Statement: Not applicable.

Data Availability Statement: The data is contained within this manuscript.

Acknowledgments: The authors thank Anthony Caro and Joaquim Claudet (CRIOBE) for giving us intestinal tracts of all the fish species. We thank Nùria Ferrer from the "Centres Cientifics i Tecnologics" of the University of Barcelona for her technical support during FTIR analyses. This study was performed within the PhD of Mel Constant funded by the "Ecole Doctorale ED305" of the University of Perpignan Via Domitia.

Conflicts of Interest: The authors declare no conflict of interest.

\section{References}

1. Galgani, F.; Hanke, G.; Maes, T. Global Distribution, Composition and Abundance of Marine Litter. In Marine Anthropogenic Litter; Bergmann, M., Gutow, L., Klages, M., Eds.; Springer International Publishing: Berlin, Germany, 2015; pp. 29-56. ISBN 978-3-319-16509-7.

2. Kenyon, K.W.; Kridler, E. Laysan Albatrosses Swallow Indigestible Matter. The Auk 1969, 86, 339-343. [CrossRef]

3. Desforges, J.-P.W.; Galbraith, M.; Ross, P.S. Ingestion of Microplastics by Zooplankton in the Northeast Pacific Ocean. Arch. Environ. Contam. Toxicol. 2015, 69, 320-330. [CrossRef] [PubMed]

4. Digka, N.; Tsangaris, C.; Torre, M.; Anastasopoulou, A.; Zeri, C. Microplastics in Mussels and Fish from the Northern Ionian Sea. Mar. Pollut. Bull. 2018, 135, 30-40. [CrossRef] [PubMed]

5. Fowler, C.W. Marine Debris and Northern Fur Seals: A Case Study. Mar. Pollut. Bull. 1987, 18, 326-335. [CrossRef]

6. Lusher, A.L.; Hernandez-Milian, G.; O’Brien, J.; Berrow, S.; O'Connor, I.; Officer, R. Microplastic and Macroplastic Ingestion by a Deep Diving, Oceanic Cetacean: The True's Beaked Whale Mesoplodon Mirus. Environ. Pollut. 2015, 199, 185-191. [CrossRef]

7. Ryan, P.G. A Brief History of Marine Litter Research. In Marine Anthropogenic Litter; Bergmann, M., Gutow, L., Klages, M., Eds.; Springer International Publishing: Berlin, Germany, 2015; pp. 1-25. ISBN 978-3-319-16509-7.

8. Ryan, P.G.; Connell, A.D.; Gardner, B.D. Plastic Ingestion and PCBs in Seabirds: Is There a Relationship? Mar. Pollut. Bull. 1988, 19, 174-176. [CrossRef]

9. Derraik, J.G.B. The Pollution of the Marine Environment by Plastic Debris: A Review. Mar. Pollut. Bull. 2002, 44, 842-852. [CrossRef]

10. Shaughnessy, P.D. Entanglement of Cape Fur Seals with Man-Made Objects. Mar. Pollut. Bull. 1980, 11, 332-336. [CrossRef]

11. Reisser, J.; Shaw, J.; Hallegraeff, G.; Proietti, M.; Barnes, D.K.A.; Thums, M.; Wilcox, C.; Hardesty, B.D.; Pattiaratchi, C. MillimeterSized Marine Plastics: A New Pelagic Habitat for Microorganisms and Invertebrates. PLoS ONE 2014, 9, e100289. [CrossRef]

12. Rochman, C.M. The Complex Mixture, Fate and Toxicity of Chemicals Associated with Plastic Debris in the Marine Environment. In Marine Anthropogenic Litter; Bergmann, M., Gutow, L., Klages, M., Eds.; Springer International Publishing: Berlin, Germany, 2015; pp. 117-140. ISBN 978-3-319-16510-3.

13. Trotter, B.; Ramsperger, A.F.R.M.; Raab, P.; Haberstroh, J.; Laforsch, C. Plastic Waste Interferes with Chemical Communication in Aquatic Ecosystems. Sci. Rep. 2019, 9, 5889. [CrossRef]

14. Plastics Europe. Plastics-The Facts 2020-An Analysis of European Plastics Production, Demand and Waste Data. Plast. Eur. 2020, 1, 1-64.

15. GESAMP; IMO/FAO/UNESCO-IOC/UNIDO/WMO/IAEA/UN/UNEP/UNDP Joint Group of Experts on the Scientific Aspects of Marine Environmental Protection. Sources, Fate and Effects of Microplastics in the Marine Environment: A Global Assessment; International Maritime Organization: London, UK, 2015.

16. Andrady, A.L. Persistence of Plastic Litter in the Oceans. In Marine Anthropogenic Litter; Bergmann, M., Gutow, L., Klages, M., Eds.; Springer International Publishing: Berlin, Germany, 2015; pp. 57-72. ISBN 978-3-319-16509-7.

17. Napper, I.E.; Bakir, A.; Rowland, S.J.; Thompson, R.C. Characterisation, Quantity and Sorptive Properties of Microplastics Extracted from Cosmetics. Mar. Pollut. Bull. 2015, 99, 178-185. [CrossRef] 
18. Albano, M.; Panarello, G.; Di Paola, D.; Capparucci, F.; Crupi, R.; Gugliandolo, E.; Spanò, N.; Capillo, G.; Savoca, S. The Influence of Polystyrene Microspheres Abundance on Development and Feeding Behavior of Artemia Salina (Linnaeus, 1758). Appl. Sci. 2021, 11, 3352. [CrossRef]

19. Albano, M.; Panarello, G.; Di Paola, D.; D’Angelo, G.; Granata, A.; Savoca, S.; Capillo, G. The Mauve Stinger Pelagia Noctiluca (Cnidaria, Scyphozoa) Plastics Contamination, the Strait of Messina Case. Int. J. Environ. Stud. 2021, 78, 977-982. [CrossRef]

20. Wieczorek, A.M.; Croot, P.L.; Lombard, F.; Sheahan, J.N.; Doyle, T.K. Microplastic Ingestion by Gelatinous Zooplankton May Lower Efficiency of the Biological Pump. Environ. Sci. Technol. 2019, 53, 5387-5395. [CrossRef]

21. Farrell, P.; Nelson, K. Trophic Level Transfer of Microplastic: Mytilus Edulis (L.) to Carcinus Maenas (L.). Environ. Pollut. 2013, 177, 1-3. [CrossRef] [PubMed]

22. Costa, E.; Piazza, V.; Lavorano, S.; Faimali, M.; Garaventa, F.; Gambardella, C. Trophic Transfer of Microplastics From Copepods to Jellyfish in the Marine Environment. Front. Environ. Sci. 2020, 8, 158. [CrossRef]

23. Galgani, F.; Fleet, D.; Van Franeker, J.; Katsanevakis, S.; Maes, T.; Mouat, J.; Oosterbaan, L.; Poitou, I.; Hanke, G.; Thompson, R.; et al. Marine Strategy Framework Directive Task Group 10 Report: Marine Litter, April 2010; Publications Office: Luxembourg, 2010.

24. Bianchi, C.N.; Morri, C. Marine Biodiversity of the Mediterranean Sea: Situation, Problems and Prospects for Future Research. Mar. Pollut. Bull. 2000, 40, 367-376. [CrossRef]

25. Cózar, A.; Sanz-Martín, M.; Martí, E.; González-Gordillo, J.I.; Ubeda, B.; Gálvez, J.Á.; Irigoien, X.; Duarte, C.M. Plastic Accumulation in the Mediterranean Sea. PLoS ONE 2015, 10, e0121762.

26. Tubau, X.; Canals, M.; Lastras, G.; Rayo, X.; Rivera, J.; Amblas, D. Marine Litter on the Floor of Deep Submarine Canyons of the Northwestern Mediterranean Sea: The Role of Hydrodynamic Processes. Prog. Oceanogr. 2015, 134, 379-403. [CrossRef]

27. Deudero, S.; Alomar, C. Mediterranean Marine Biodiversity under Threat: Reviewing Influence of Marine Litter on Species. Mar. Pollut. Bull. 2015, 98, 58-68. [CrossRef] [PubMed]

28. Fossi, M.C.; Pedà, C.; Compa, M.; Tsangaris, C.; Alomar, C.; Claro, F.; Ioakeimidis, C.; Galgani, F.; Hema, T.; Deudero, S.; et al. Bioindicators for Monitoring Marine Litter Ingestion and Its Impacts on Mediterranean Biodiversity. Environ. Pollut. 2018, 237, 1023-1040. [CrossRef]

29. Galgani, F.; Souplet, A.; Cadiou, Y. Accumulation of Debris on the Deep Sea Floor off the French Mediterranean Coast. Mar. Ecol. Prog. Ser. 1996, 142, 225-234. [CrossRef]

30. Durrieu de Madron, X.; Guieu, C.; Sempéré, R.; Conan, P.; Cossa, D.; D’Ortenzio, F.; Estournel, C.; Gazeau, F.; Rabouille, C.; Stemmann, L.; et al. Marine Ecosystems' Responses to Climatic and Anthropogenic Forcings in the Mediterranean. Prog. Oceanogr. 2011, 91, 97-166. [CrossRef]

31. Collard, F.; Gilbert, B.; Compère, P.; Eppe, G.; Das, K.; Jauniaux, T.; Parmentier, E. Microplastics in Livers of European Anchovies (Engraulis Encrasicolus, L.). Environ. Pollut. 2017, 229, 1000-1005. [CrossRef] [PubMed]

32. Collard, F.; Gilbert, B.; Eppe, G.; Parmentier, E.; Das, K. Detection of Anthropogenic Particles in Fish Stomachs: An Isolation Method Adapted to Identification by Raman Spectroscopy. Arch. Environ. Contam. Toxicol. 2015, 69, 331-339. [CrossRef]

33. Collard, F.; Gilbert, B.; Eppe, G.; Roos, L.; Compère, P.; Das, K.; Parmentier, E. Morphology of the Filtration Apparatus of Three Planktivorous Fishes and Relation with Ingested Anthropogenic Particles. Mar. Pollut. Bull. 2017, 116, 182-191. [CrossRef]

34. Lefebvre, C.; Saraux, C.; Heitz, O.; Nowaczyk, A.; Bonnet, D. Microplastics FTIR Characterisation and Distribution in the Water Column and Digestive Tracts of Small Pelagic Fish in the Gulf of Lions. Mar. Pollut. Bull. 2019, 142, 510-519. [CrossRef]

35. Pennino, M.G.; Bachiller, E.; Lloret-Lloret, E.; Albo-Puigserver, M.; Esteban, A.; Jadaud, A.; Bellido, J.M.; Coll, M. Ingestion of Microplastics and Occurrence of Parasite Association in Mediterranean Anchovy and Sardine. Mar. Pollut. Bull. 2020, 158, 111399. [CrossRef]

36. Durrieu de Madron, X.; Abassi, A.; Heussner, S.; Monaco, A.; Aloisi, J.C.; Radakovitch, O.; Giresse, P.; Buscail, R.; Kerherve, P. Particulate Matter and Organic Carbon Budgets for the Gulf of Lions (NW Mediterranean). Oceanol. Acta 2000, 23, 717-730. [CrossRef]

37. Ludwig, W.; Dumont, E.; Meybeck, M.; Heussner, S. River Discharges of Water and Nutrients to the Mediterranean and Black Sea: Major Drivers for Ecosystem Changes during Past and Future Decades? Prog. Oceanogr. 2009, 80, 199-217. [CrossRef]

38. Bouloubassi, I.; Roussiez, V.; Azzoug, M.; Lorre, A. Sources, Dispersal Pathways and Mass Budget of Sedimentary Polycyclic Aromatic Hydrocarbons (PAH) in the NW Mediterranean Margin, Gulf of Lions. Mar. Chem. 2012, 142-144, 18-28. [CrossRef]

39. Sadaoui, M.; Ludwig, W.; Bourrin, F.; Raimbault, P. Controls, Budgets and Variability of Riverine Sediment Fluxes to the Gulf of Lions (NW Mediterranean Sea). J. Hydrol. 2016, 540, 1002-1015. [CrossRef]

40. Courp, T.; Monaco, A. Sediment Dispersal and Accumulation on the Continental Margin of the Gulf of Lions: Sedimentary Budget. Cont. Shelf Res. 1990, 10, 1063-1087. [CrossRef]

41. Avio, C.G.; Gorbi, S.; Regoli, F. Experimental Development of a New Protocol for Extraction and Characterization of Microplastics in Fish Tissues: First Observations in Commercial Species from Adriatic Sea. Mar. Environ. Res. 2015, 111, 18-26. [CrossRef]

42. Löder, M.G.J.; Gerdts, G. Methodology Used for the Detection and Identification of Microplastics-A Critical Appraisal. In Marine Anthropogenic Litter; Bergmann, M., Gutow, L., Klages, M., Eds.; Springer International Publishing: Berlin, Germany, 2015; pp. 201-227. ISBN 978-3-319-16509-7.

43. Thompson, R.C.; Olsen, Y.; Mitchell, R.P.; Davis, A.; Rowland, S.J.; John, A.W.G.; McGonigle, D.; Russell, A.E. Lost at Sea: Where Is All the Plastic? Science 2004, 304, 838. [CrossRef] 
44. Louisy, P. Guide D'identification Des Poissons Marins: Europe De l'ouest et Méditerranée; Editions Eugen Ulmer: Paris, France, 2002; ISBN 2-84138-651-1.

45. Harmelin, J.-G.; Ruitton, S. Poissons de Méditerranée; Edisud: Biganos, France, 2013; ISBN 978-2-7449-0992-4.

46. Weinberg, S. Découvrir La Vie Sous-Marine Méditerranée; Guardian Angel Publishing: Saint Louis, MO, USA, 2013; ISBN 2-74170533-X.

47. Froese, R.; Pauly, D. FishBase. Available online: www.fishbase.org (accessed on 13 November 2021).

48. Pellini, G.; Gomiero, A.; Fortibuoni, T.; Ferrà, C.; Grati, F.; Tassetti, A.N.; Polidori, P.; Fabi, G.; Scarcella, G. Characterization of Microplastic Litter in the Gastrointestinal Tract of Solea Solea from the Adriatic Sea. Environ. Pollut. 2018, 234, 943-952. [CrossRef] [PubMed]

49. Anastasopoulou, A.; Kovač Viršek, M.; Bojanić Varezić, D.; Digka, N.; Fortibuoni, T.; Koren, Š.; Mandić, M.; Mytilineou, C.; Pešić, A.; Ronchi, F.; et al. Assessment on Marine Litter Ingested by Fish in the Adriatic and NE Ionian Sea Macro-Region (Mediterranean). Mar. Pollut. Bull. 2018, 133, 841-851. [CrossRef] [PubMed]

50. Gajšt, T.; Bizjak, T.; Palatinus, A.; Liubartseva, S.; Kržan, A. Sea Surface Microplastics in Slovenian Part of the Northern Adriatic. Mar. Pollut. Bull. 2016, 113, 392-399. [CrossRef]

51. Constant, M.; Kerhervé, P.; Mino-Vercellio-Verollet, M.; Dumontier, M.; Sànchez Vidal, A.; Canals, M.; Heussner, S. Beached Microplastics in the Northwestern Mediterranean Sea. Mar. Pollut. Bull. 2019, 142, 263-273. [CrossRef]

52. Alomar, C.; Deudero, S. Evidence of Microplastic Ingestion in the Shark Galeus Melastomus Rafinesque, 1810 in the Continental Shelf off the Western Mediterranean Sea. Environ. Pollut. 2017, 223, 223-229. [CrossRef]

53. Bellas, J.; Martínez-Armental, J.; Martínez-Cámara, A.; Besada, V.; Martínez-Gómez, C. Ingestion of Microplastics by Demersal Fish from the Spanish Atlantic and Mediterranean Coasts. Mar. Pollut. Bull. 2016, 109, 55-60. [CrossRef] [PubMed]

54. Güven, O.; Gökdağ, K.; Jovanović, B.; Kıdeyş, A.E. Microplastic Litter Composition of the Turkish Territorial Waters of the Mediterranean Sea, and Its Occurrence in the Gastrointestinal Tract of Fish. Environ. Pollut. 2017, 223, 286-294. [CrossRef]

55. Compa, M.; Ventero, A.; Iglesias, M.; Deudero, S. Ingestion of Microplastics and Natural Fibres in Sardina Pilchardus (Walbaum, 1792) and Engraulis Encrasicolus (Linnaeus, 1758) along the Spanish Mediterranean Coast. Mar. Pollut. Bull. 2018, 128, 89-96. [CrossRef] [PubMed]

56. Nadal, M.A.; Alomar, C.; Deudero, S. High Levels of Microplastic Ingestion by the Semipelagic Fish Bogue Boops Boops (L.) around the Balearic Islands. Environ. Pollut. 2016, 214, 517-523. [CrossRef] [PubMed]

57. Alomar, C.; Sureda, A.; Capó, X.; Guijarro, B.; Tejada, S.; Deudero, S. Microplastic Ingestion by Mullus Surmuletus Linnaeus, 1758 Fish and Its Potential for Causing Oxidative Stress. Environ. Res. 2017, 159, 135-142. [CrossRef]

58. Napper, I.E.; Thompson, R.C. Release of Synthetic Microplastic Plastic Fibres from Domestic Washing Machines: Effects of Fabric Type and Washing Conditions. Mar. Pollut. Bull. 2016, 112, 39-45. [CrossRef] [PubMed]

59. Consoli, P.; Andaloro, F.; Altobelli, C.; Battaglia, P.; Campagnuolo, S.; Canese, S.; Castriota, L.; Cillari, T.; Falautano, M.; Pedà, C.; et al. Marine Litter in an EBSA (Ecologically or Biologically Significant Area) of the Central Mediterranean Sea: Abundance, Composition, Impact on Benthic Species and Basis for Monitoring Entanglement. Environ. Pollut. 2018, 236, 405-415. [CrossRef]

60. Cole, M. A Novel Method for Preparing Microplastic Fibers. Sci. Rep. 2016, 6, 34519. [CrossRef]

61. Garcia-Garin, O.; Vighi, M.; Aguilar, A.; Tsangaris, C.; Digka, N.; Kaberi, H.; Borrell, A. Boops Boops as a Bioindicator of Microplastic Pollution along the Spanish Catalan Coast. Mar. Pollut. Bull. 2019, 149, 110648. [CrossRef]

62. Rios-Fuster, B.; Alomar, C.; Compa, M.; Guijarro, B.; Deudero, S. Anthropogenic Particles Ingestion in Fish Species from Two Areas of the Western Mediterranean Sea. Mar. Pollut. Bull. 2019, 144, 325-333. [CrossRef] [PubMed]

63. Sbrana, A.; Valente, T.; Scacco, U.; Bianchi, J.; Silvestri, C.; Palazzo, L.; De Lucia, G.A.; Valerani, C.; Ardizzone, G.; Matiddi, M. Spatial Variability and Influence of Biological Parameters on Microplastic Ingestion by Boops Boops (L.) along the Italian Coasts (Western Mediterranean Sea). Environ. Pollut. 2020, 263, 114429. [CrossRef]

64. Tsangaris, C.; Digka, N.; Valente, T.; Aguilar, A.; Borrell, A.; De Lucia, G.A.; Gambaiani, D.; Garcia-Garin, O.; Kaberi, H.; Martin, J.; et al. Using Boops Boops (Osteichthyes) to Assess Microplastic Ingestion in the Mediterranean Sea. Mar. Pollut. Bull. 2020, 158, 111397. [CrossRef]

65. Giani, D.; Baini, M.; Galli, M.; Casini, S.; Fossi, M.C. Microplastics Occurrence in Edible Fish Species (Mullus Barbatus and Merluccius Merluccius) Collected in Three Different Geographical Sub-Areas of the Mediterranean Sea. Mar. Pollut. Bull. 2019, 140, 129-137. [CrossRef] [PubMed]

66. Capillo, G.; Savoca, S.; Panarello, G.; Mancuso, M.; Branca, C.; Romano, V.; D’Angelo, G.; Bottari, T.; Spanò, N. Quali-Quantitative Analysis of Plastics and Synthetic Microfibers Found in Demersal Species from Southern Tyrrhenian Sea (Central Mediterranean). Mar. Pollut. Bull. 2020, 150, 110596. [CrossRef]

67. Savoca, S.; Capillo, G.; Mancuso, M.; Bottari, T.; Crupi, R.; Branca, C.; Romano, V.; Faggio, C.; D’Angelo, G.; Spanò, N. Microplastics Occurrence in the Tyrrhenian Waters and in the Gastrointestinal Tract of Two Congener Species of Seabreams. Environ. Toxicol. Pharmacol. 2019, 67, 35-41. [CrossRef] [PubMed]

68. Avio, C.G.; Cardelli, L.R.; Gorbi, S.; Pellegrini, D.; Regoli, F. Microplastics Pollution after the Removal of the Costa Concordia Wreck: First Evidences from a Biomonitoring Case Study. Environ. Pollut. 2017, 227, 207-214. [CrossRef]

69. Foekema, E.M.; De Gruijter, C.; Mergia, M.T.; Van Franeker, J.A.; Murk, A.J.; Koelmans, A.A. Plastic in North Sea Fish. Environ. Sci. Technol. 2013, 47, 8818-8824. [CrossRef] [PubMed] 
70. Welden, N.A.; Abylkhani, B.; Howarth, L.M. The Effects of Trophic Transfer and Environmental Factors on Microplastic Uptake by Plaice, Pleuronectes Plastessa, and Spider Crab, Maja Squinado. Environ. Pollut. 2018, 239, 351-358. [CrossRef]

71. Romeo, T.; Pietro, B.; Pedà, C.; Consoli, P.; Andaloro, F.; Fossi, M.C. First Evidence of Presence of Plastic Debris in Stomach of Large Pelagic Fish in the Mediterranean Sea. Mar. Pollut. Bull. 2015, 95, 358-361. [CrossRef]

72. Romeo, T.; Peda, C.; Fossi, M.C.; Andaloro, F.; Battaglia, P. First Record of Plastic Debris in the Stomach of Mediterranean Lanternfishes. Acta Adriat. 2016, 57, 115-122. 